\title{
Accelerated neuroregulation for therapy of opiate dependency
}

\author{
S. Sunatrio, L. Rachmat, G. Darmansyah, Y. Thedja
}

\begin{abstract}
Abstrak
Penyapihan akut dari penyalahgunaan opioid kronik selama anestesia umum, umumnya disertai gejala akibat keluarnya adrenalin. Makalah ini melaporkan pengalaman kami dalam neuroregulasi yang dipercepat untuk memulihkan ketergantungan fisik dan psikologik. Sesudah pemeriksaan medik dan psikologik yang menyeluruh, 361 pasien pecandu heroin dirawat di ICU selama 24-36 jam, yang mencakup proses pengobatan praprosedur 6 jam (solbutamol, klonidin, diazepam, ranitidin, omeprazol, vitamin $C$, oktreotid, dan ondansetron). Anestesia dimulai dengan midazolam dan propofol iv dan dipertahankan dengan infusi propofol. Naltrekson, klonidin, oktreotid, dan diazepam diberikan setelah itu. Anestesia dipertahankan selama 3 1/2 - 5 jam tergantung pada keparahan gejala-gejala putus obat yang dicetuskan oleh naltrekson. Sesudahnya, analgetik dan sedatif diberikan seperlunya. Sewaktu dipulangkan pada keesokan harinya, pasien diberi resep naltrekson oral selama 10-12 bulan. Detoksifikasi berhasil pada semua pasien tanpa efek samping anestesia yang tidak diinginkan. Efek samping yang dijumpai adalah capai, insomnia, mengantuk, menggigil, nyeri perut, mual, diare, mialgia, bulu roma merinding dan rasa tak nyaman. Pada kebanyakan pasien gejala-gejala ini menghilang tanpa pengobatan. Terapi simptomatik diperlukan pada 32,7\% pasien. Pada semua pasien yang menyelesaikan terapi rumatan naltrekson (166 orang) 'craving' menghilang pada bulan ke 10. Masalah utama adalah kepatuhan pasien yang rendah terhadap naltrekson oral, sehingga hanya 45,9\% pasien yang menyelesaikan terapi. Kesimpulan: neuroregulasi yang dipercepat yang mencakup terapi pemeliharaan naltrekson (10-12 bulan) sangat efektif untuk detoksifikasi dan untuk menghilangkan craving pada pasien pecandu heroin. (Med J Indones 2004; 13: 53-8)
\end{abstract}

\begin{abstract}
Acute weaning from chronic opioid abuse during general anesthesia is usually followed by adrenergic outflow effects. This article is to report our experience with accelerated neuroregulation that reverses the physical and psychological dependency. After a comprehensive psychological and medical examination, 361 heroin dependent patients were admitted to ICU to be hospitalized for a full 24 or 36 hours, including a 6 hour pre-procedure medication process (solbutamol, clonidine, diazepam, ranitidine, omeprazole, vitamin $C$, octreotide, and ondansetron). Anesthesia was induced with midazolam and propofol iv and maintained with propofol infusion. Naltrexon, clonidine, octreotide, and diazepam were then administered. Anesthesia was maintained for 3 1/2 - 5 hours depending on severity of withdrawal symptoms precipitated by naltrexone. Analgetics and sedatives were given as needed afterwards. Upon discharge on the following day, patient was prescribed a regimen of oral naltrexone for 10-12 months. All 361 patients were successfully detoxified without any adverse anesthetic events. The side effects encountered were fatigue, insomnia, drowsy, shivering, abdominal pain, nausea, diarrhoea, myalgia, goose bumps and uncomfortable feeling. In most of the patients these symptoms disappeared without any treatment. Symptomatic treatments were needed in $32.7 \%$ of patients. In all 166 patients who completed their naltrexone maintenance treatment, craving disappeared in the $10^{\text {th }}$ month. The main problem was the low patient compliance to oral naltrexone, so that only $45.9 \%$ of the patients completed their therapy. Conclusion: Accelerated neuroregulation which includes naltrexone maintenance treatment (10-12 months) was highly effective to detoxify and to abolish craving in the heroin dependent patients. (Med J Indones 2004; 13: 53-8)
\end{abstract}

Keywords: detoxification, craving management

Many of opiate addicts want to and even try to undergo detoxification using traditional withdrawal methodology, which involves a tapering of methadone

Department of Anesthesiology / ICU, Graha Medika Hospital, Jakarta, Indonesia dosages. However, this is frequently unsuccessful. In general, rehabilitation of people addicted to opioids can only begin after an initial and variable period of abstinence. The "withdrawal syndrome" is often extremely unpleasant, may even be fatal, and deters patients from the detoxification process. Conventional detoxification methods have included tapering doses of substitute agonist drugs and use of $\mu$ opioid 
receptor antagonists. The time required is three to 21 days. Admission for inpatient monitoring may be necessary, and initial drop out rates range from $30 \%$ to $91 \%{ }^{1-3}$ Rapid opiate detoxification (ROD) requires administration of small amounts of narcotic antagonists while awake. The addition of clonidine to modify the symptoms of withdrawal was first described about 17 years ago. ${ }^{4}$ It has similarly been plagued by poor success rates, mainly because of the severe pain associated with the process. Considerable popular attention has focused on the utilization of general anesthesia during the acute phase of antagonist precipitated opioid withdrawal. This acute weaning from chronic opioid abuse during general anesthesia is usually followed by an adrenergic outflow effect. This article aims to report our experience with accelerated neuroregulation that reverses the physical and psychological dependency. The method comprised of detoxification which cleaned the body from the narcotics, and was followed by naltrexone (NTX) maintenance therapy which ensured and maintained patient abstinence from opiates in craving management.

\section{METHODS}

During August 1999 - November 2002, in the Graha Medika Hospital, Jakarta, heroin dependent patients were admitted to ICU to be hospitalized for a full 24 to 36 hours, including a 6 hour pre-procedure medication process.

After a comprehensive psychological and medical examination the patients were admitted to ICU. During the first 5 hours every patient was premedicated with: solbutamol $2.5 \mathrm{mg}$ by inhalation, and oral vitamin C $(1000 \mathrm{mg})$, clonidine $(0.375 \mathrm{mg})$, diazepam $(10 \mathrm{mg})$, ranitidine $(150 \mathrm{mg})$, and omeprazole (20 mg), and subcutaneous/sc octreotide $(0.05 \mathrm{mg})$. Anesthesia was induced with midazolam $(2-3 \mathrm{mg}$, intravenous/iv) and propofol (100-120 mg, iv), and the patient was then intubated. Thereafter anesthesia was maintained with propofol infusion 4-12 $\mathrm{mg} / \mathrm{kg} /$ hour for a period of 4 to 5 hours. During anesthesia, the following drugs were also administered: ondansetron (4 mg, iv), octreotide $(0.15 \mathrm{mg}$, sc), and ranitidine $(50 \mathrm{mg}$, iv). After induction of anesthesia, NTX (50-87.5 mg), clonidine $(0.375-0.525 \mathrm{mg})$ and diazepam $(10 \mathrm{mg})$ were administered through orogastric tube. At the end of the anesthesia the patient was extubated. During anesthesia, infusion of D5R $(1000 \mathrm{~mL})$ and Ringer's solution $(1500 \mathrm{~mL})$ were given. Post-detoxification, at night every patient was given oral diazepam $(10 \mathrm{mg})$, and clonidine $(0.075 \mathrm{mg})$. Early in the morning on the first postdetoxification day (PDD), the patient was infused with D5W $(1 \mathrm{~L})+15 \mathrm{mEq} \mathrm{KCl}$, and ranitidine 150 $\mathrm{mg}$, clonidine $0.075 \mathrm{mg}$, NTX $25 \mathrm{mg}$, paracetamol $500 \mathrm{mg}$, and vitamin C $500 \mathrm{mg}$ were administered orally. Afterwards, the patients had breakfast and were allowed to leave the hospital. The NTX (25-50 $\mathrm{mg}$ ) was given orally for 7-10 days beginning at the $2^{\text {nd }} \mathrm{PPD}$, and then $25 \mathrm{mg}$ for 10-12 months depending on the severity of opiate addiction. In the first 2 months post-detoxification every patient was contacted regularly (by phone or face to face) to detect any side effect which may develope and to be treated symptomatically if needed. Craving scale was also scored every month for 10-12 months by using visual analog scale. Every three months SGOT and SPGT were measured.

\section{RESULTS}

During August 1999 - November 2002, in the Graha Medika Hospital, Jakarta, 361 heroin dependent patients (329 males, 32 females) were admitted to ICU to be hospitalized for a full 24 to 36 hours, including a 6 hour pre-procedure medication process. Their mean age is 22 years (range: $16-45$ years), mean duration of heroin use $=6$ years (range: 8 months - 10 years). The route of heroin administration: $70 \%$ by intravenous injection, and $30 \%$ by inhalation.

All 361 patients were successfully detoxified without any adverse anesthetic events. This was proved by the absence of withdrawal syndrome after NTX administration. The total number of patients supposed to complete their NTX maintenance therapy for 10-12 months was 326. In fact, the total number of patients which could be contacted was 274 . Among them, the patients who completed the NTX maintenance therapy (100\% compliance) were only 166, while 114 patients were dropped out (including the 52 patients which could not be contacted). Most of the drop out patients were teenagers. The patient compliance to NTX therapy had a tendency to decrease according to time (see figure 1). Figure 2 shows that patient's craving scale dropped to $\pm 50 \%$ after detoxification. In all 166 patients who completed their NTX maintenance 
treatment, craving disappeared in the $10^{\text {th }}$ month. Figure 3 shows the craving score of all patients who completed their NTX maintenance treatment. After 10 months the patient was considered recovered in term of having no craving and no withdrawal syndrome. Post- detoxification side effects could be seen on the table 1 . Symptomatic therapy of side effects was needed only in 103 patients (32.7\%) and the symptoms in the rest of patients disappeared spontaneously. No impairment of liver function due to NTX was found in all patients.

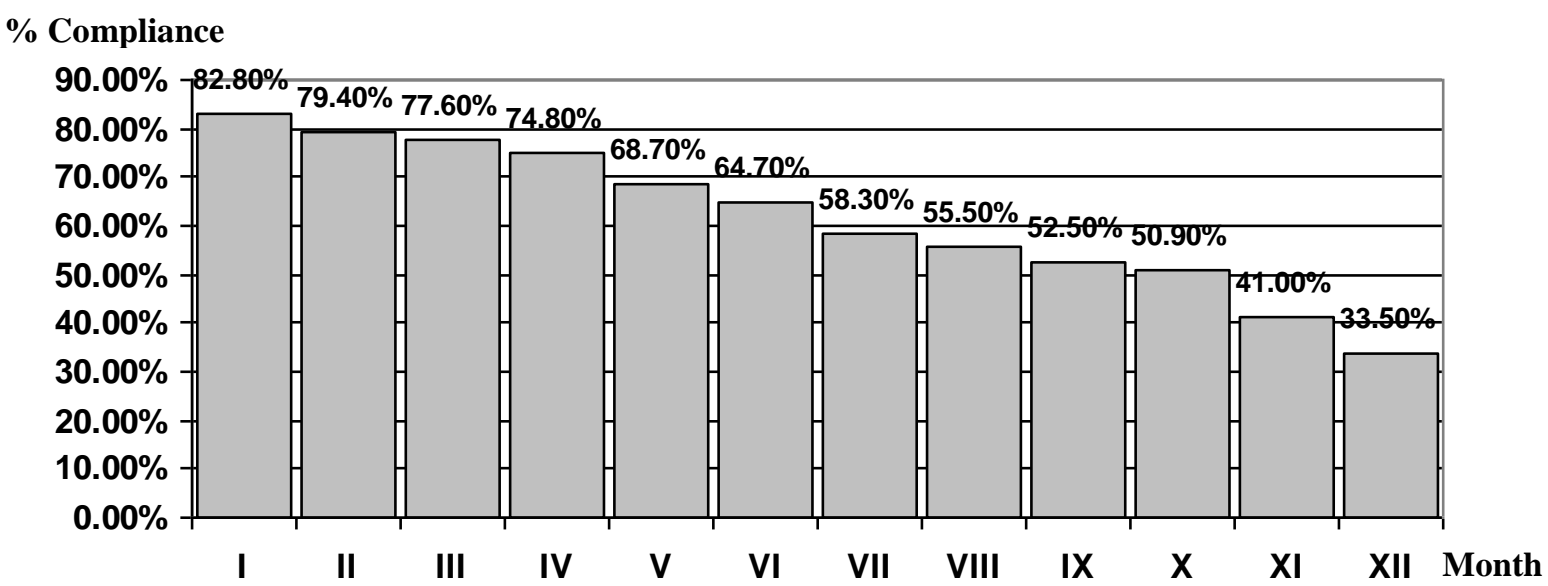

Figure 1. Patient compliance to naltrexon oral therapy in the 326 patients supposed to complete their therapy for 10-12 months

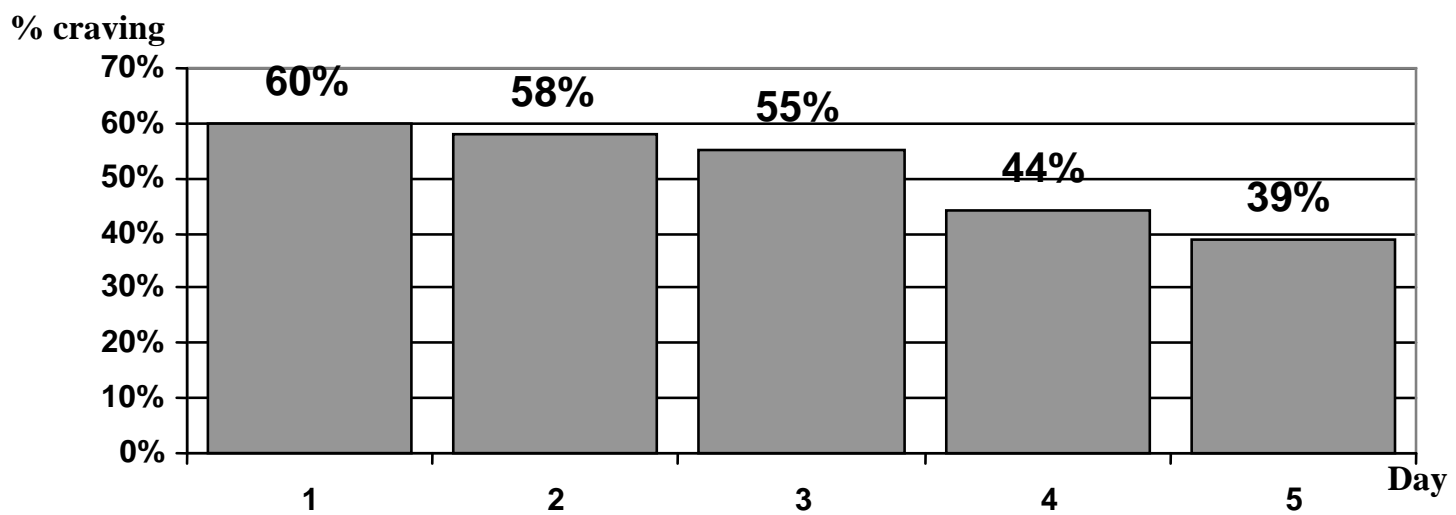

Figure 2. Average craving score in 315 patients on the post-detoxification day 1-5

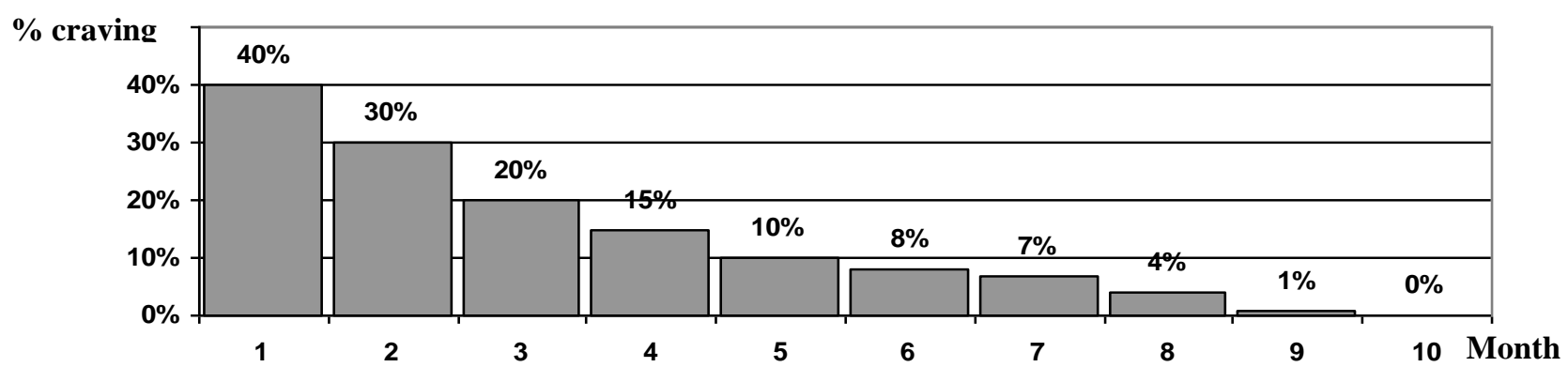

Figure 3. Average craving score in 166 patients who completed their naltrexon maintenance therapy 
Table 1. Post-detoxification side effects in 315 patients

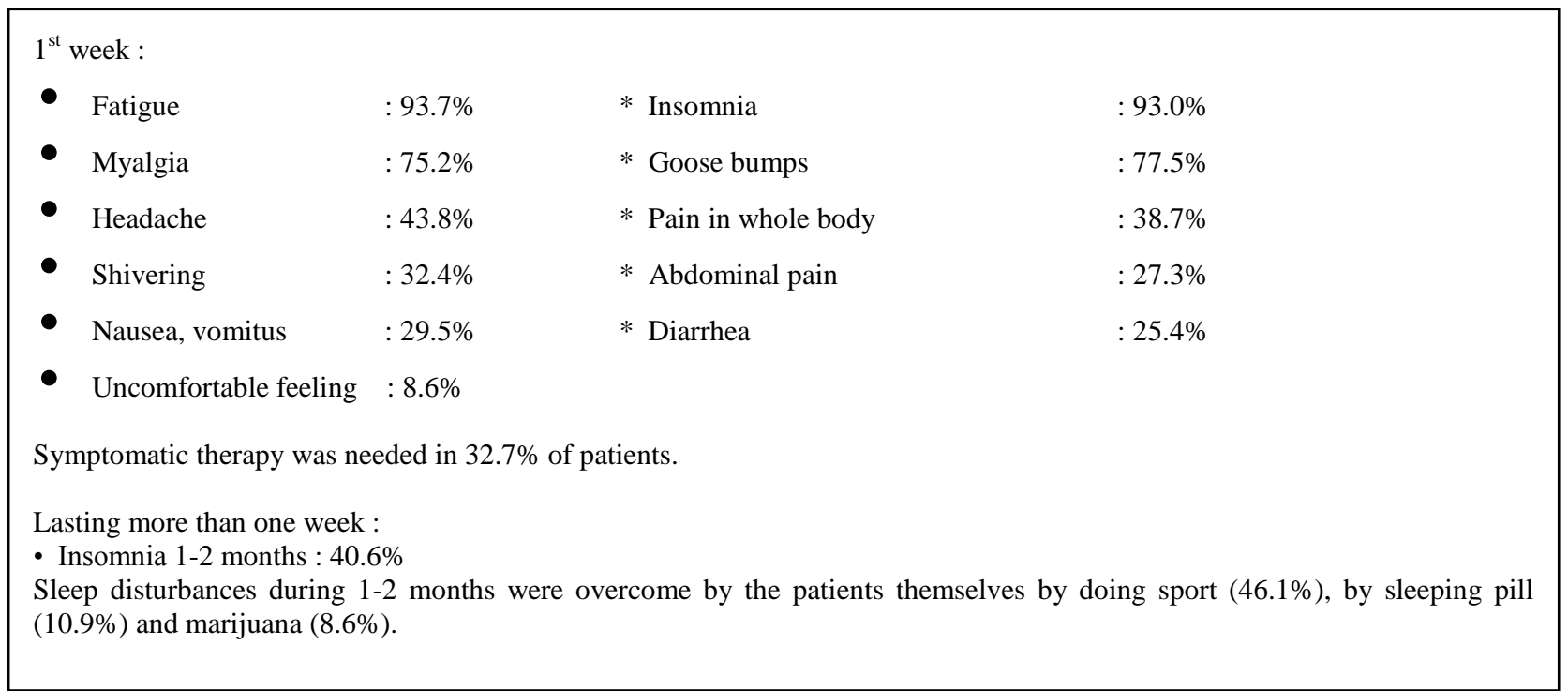

\section{DISCUSSION}

Ultra rapid opiate detoxification (UROD) involves the administration of general anesthesia prior to the administration of narcotic antagonists. It is generally $100 \%$ successful in detoxification and allows establishment of a therapeutic level of long-acting antagonists. ${ }^{5-8}$ In essence, the withdrawal syndrome is deconstructed and each component aggressively treated. However, the process is not without discomfort, and its use is controversial in some areas, mainly due to marketing strategy.

The increase in heroin dependence has led to renewed interest in improving methods of opioid detoxification. The utilization of general anesthesia during the acute phase of antagonist-precipitated opioid withdrawal is becoming more popular, but there is only a few of controlled studies of these techniques. In particular follow up data from a random sample of patients detoxified under general anesthesia are not enough available. This is a critical issue since the increasing number of related deaths requires a risk / benefit analysis.

The following is the first randomized clinical trial done by Currie et al, ${ }^{8}$ who compared clinical efficacy, safety and cost effectiveness of anesthesia-assisted vs sedation-assisted rapid induction onto naltrexone (NTX) (aa-RION vs sa-RION). They also compared clinical efficacy and cost effectiveness of these RION techniques with induction onto NTX following conventional inpatient or ambulatory detoxification (CONV) using a naturalistic patient cohort. Finally, they examined the influence of RION vs CONV induction techniques on long-term outcomes of NTXsupported abstinence maintenance programs over the 12 months following induction. One hundred and fifty patients were enrolled into aa-RION ( $n=47)$, saRION $(n=70)$, or CONV $(n=33)$ protocols. Male= 90 , mean age $=30.5$ years. Heroin user $(\mathrm{HU}): \mathrm{n}=74$, mean duration of use $=7.2$ years, mean daily dose $=$ $590 \mathrm{mg}$. Methadone users (MU): $\mathrm{n}=76$, mean duration of use $=9.7$ years, mean daily dose $=87 \mathrm{mg}$. Rates for successful induction on NTX were: aa$\mathrm{RION}=98 \%$, sa-RION $=99 \%, \mathrm{CONV}$ (inpatient $)=$ $37 \%$, CONV (ambulatory) $=17 \% \quad(P<0.001)$. With octreotide only $5 \%$ had appreciable vomiting or diarrhoea, but transient encephalopathy was common $(88 \%)$. Mean duration of inpatient stay $=1.5-1.9$ days. Residual withdrawal symptoms were common up to 2 weeks and insomnia up to 6 weeks. Relative costs per successful induction onto NTX were significantly less for RION (A\$2,000) compared to CONV techniques (A \$ 6,000 - A \$ 7,000). Outcomes at 12 months were: (1) non-dependent on opiates (confirmed by supervised NTX challenge): $\mathrm{HU}=59 \%, \mathrm{MU}=62 \%$; (2) $(\mathrm{Re})$ commenced methadone maintenance: $\mathrm{HU}=$ $16 \%, \mathrm{MU}=25 \%$; therefore (3) total of patients remaining in medical treatment: $\mathrm{HU}=75 \%, \mathrm{MU}=$ $87 \%$; (4) known or presumed to have relapsed to be dependent heroin user: $\mathrm{HU}=25 \%, \mathrm{MU}=13 \%$. 
Geographically isolated rural patients had significantly higher relapse rates than metropolitan patients local to the programme ( $80 \%$ vs. $25 \%$ relapse, $P=0.001$ ). Their conclusions: For patients seeking to undertake an abstinence based model of treatment, aa-RION and saRION techniques are safe, highly effective, cost efficient and very acceptable to patients, and therefore are cost effective methods for commencing NTX supported abstinence maintenance. ${ }^{8}$

Using PET scan, the conditions in the brain of opiate addicted patient was revealed. The primary disorder is proliferation of $\mu$ opiate receptors in the brain that can increase up to 600 times or more. ${ }^{6}$ Recently, treatments to reverse this condition is available. So far, drug addicts have been treated by psychiatrists and psychologists, but their suffering is primarily not a psychological problem. Instead, it is a neurological problem that causes secondary psychological effects.

The techniques of UROD is designed to shorten the detoxification process to a four to six hour period by precipitating withdrawal with opioid antagonist administration. ${ }^{9-10}$ Because withdrawal syndrome are frequently severe and may even life-threatening, administration of deep sedation or general anesthesia is used to blunt or prevent the patient's awareness of the physical pain. Strict monitoring of the cardiorespiratory status and detection of any changes allows the anesthesiologist to make appropriate correction immediately. During the detoxification process, a large proportion of opiate will leave the patient's body. When there is no more opiate available, the body starts the process of neuroregulation which last for 10-14 months with the use of NTX.

Opiate dependency is a physical illness, not a social disorder, therefore it must be treated accordingly. The war against opiate can not be won if the opiate addicted patients are not effectively treated. To achieve this, the holistic approach should be employed i.e. medico-psycho-socio-spiritual approaches. We suggest that these consist of accelerated neuroregulation and psycho-socio-spiritual supports. Accelerated neuroregulation is an effective, efficient, safe and humane treatment without fear of pain and provides the patient a chance to go back soon to daily normal life in craving management process.

This report showed that NTX was very effective in opioid detoxification process and for craving management, but its clinical efficacy was limited by a poor compliance in oral medication. The low patient compliance in our report is a universal problem in the use of oral NTX. Most of the patients with poor compliance were teenagers with weak motivation and some of them were forced by their families to get therapy. As an alternative, NTX implants were effective means of stopping relapse while they were active. ${ }^{11}$ Naltrexon implant was better than NTX oral in relapse prevention. ${ }^{12,13}$

The symptoms occurring after detoxification could be residual withdrawal syndrome precipitated by NTX or the side effects of NTX itself. These symptoms were aggravated by low endorphin level in the patient's blood due to chronic use of exogenous heroin, while the heroin had been washed out from the brain. In order to relieve these symptoms quickly, it is necessary to stimulate the endorphin production by early patient ambulation and encouraging the patient to do sports.

In conclusion, accelerated neuroregulation which included NTX maintenance treatment for 10-12 months was highly effective to detoxify and to abolish craving in the heroin dependent patients.

\section{REFERENCES}

1. Mattick RP, Hall W. Are detoxification programme effective? Lancet 1996;347:97-100.

2. Gold ML, Sorensen JL, McCanlies N. Tapering from methadone maintenance: Attitudes of clients and staff. J Subt Abuse Treat 1998;5:37-44.

3. Azatian A, Papiasvili A, Joseph H. A study of the use of clonidine and naltrexone in the treatment of opioid addiction in the former U.S.S.R. J Addict Dis 1994;13:3552.

4. Simon DL. The rationale for naltrexone therapy as an alternative to methadone treatment for opiate addiction. Conn Med 1996;60:683-5.

5. Presslich O, Loimer N. Opiate detoxification under general anesthesia by large doses of naltrexone. Clin toxicol 1989;27:263-70.

6. Waisman A. Personal communication. Megama, The Israeli Institute of Advanced Treatment and Research for Opiate Dependency, Tel Aviv, Israel. http://www.megama.com/about.html.

7. Sunatrio S, Rachmat L, Darmansyah G, Thedja Y. Accelerated neuroregulation for therapy of opiate dependency. A preliminary report. Presented in the $12^{\text {th }}$ Asean Congress of Anesthesiologists; 2001 Nov 13-17; Cebu, The Phillipines.

8. Currie J, Cox P, Collins L, Mudaliar Y, Gaunt L, Esposito $\mathrm{J}$, et al. Rapid antagonist induction / rapid induction onto naltrexone: A randomised clinical trial of anesthesia- 
assisted versus sedation-assisted techniques, and a comparison with conventional detoxification. Presented in the $6^{\text {th }}$ International Conference Royal Society of Medicine. A two-day conference on Advances in Antagonist-Assisted Abstinence; Rapid Opiate Detoxification and Naltrexone Treatment; 2001 Apr 1112; London, England.

9. Simon DL. Rapid opioid detoxification using opioid antagonists: History, theory and the state of the art. J Addict Dis 1997;16:103-22.

10. Legardo JJ, Gossup M. A 24-hour inpatient detoxification treatment for heroin addicts: A preliminary investigation. Drug Alcohol Depend 1994;35:91-3.

11. Steele T, Brewer C. Three months outcome in naltrexone implanted patients following the Asturian detoxification techniques. Presented in the $6^{\text {th }}$ International Conference Royal Society of Medicine. A two-day conference on Advances in Antagonist-Assisted Abstinence; Rapid
Opiate Detoxification and Naltrexone Treatment; 2001 Apr 11-12; London, England.

12. Gölz J. Partecke L, Veith S, Latasch L. Follow up of opiate addict after rapid opiate detoxification under anesthesia; relapse prophylaxis with naltrexone orally and subcuntaneously implanted with psychological care. Presented in the $6^{\text {th }}$ International Conference Royal Society of Medicine. A two-day conference on Advances in Antagonist-Assisted Abstinence; Rapid Opiate Detoxification and Naltrexone Treatment; 2001 Apr 1112; London, England.

13. Carreno JE, Alvarez CE, San Narciso GI, Bascaran MT, Cerceda A, Brewer C, et al. Maintenance treatment with a depot opioid antagonist (naltrexone) in subcutaneous implants: an alternative in the treatment of opioid dependence. Presented in the $7^{\text {th }}$ International Stapleford Conference on addiction management; 2002 Nov 13-15; Nijmegen, The Netherlands. 